\title{
Jurist-Diction
}

Volume 4 No. 2, Maret 2021

\section{Prinsip Penegakan Hukum dan Hak Asasi Manusia: Studi Kasus Penembakan Militer Terhadap Masyarakat Nduga Papua}

\author{
Andrean Gregorius Pandapotan Simamora dan \\ Georgius Ivan Budihardja \\ sandreangregorius@yahoo.com \\ Universitas Airlangga
}

\begin{abstract}
How to cite:
Andrean Gregorius Pandapotan

Simamora dan Georgius Ivan Budihardja'Prinsip

Penegakan Hukum Dan Hak

Asasi Manusia: Studi Kasus

Penembakan Militer Terhadap

Masyarakat Nduga Papua'

(2021) Vol. 4 No. 2 Jurist-

Diction.
\end{abstract}

Histori artikel:

Submit 09 Januari 2021;

Diterima 18 Februari 2021;

Diterbitkan 1 Maret 2021.

DOI:

10.20473/jd.v4i2.25750

p-ISSN: 2721-8392

e-ISSN: $2655-8297$

\section{Abstract}

Human rights violations in Papua that have occurred (in the last 10 years) are many factors that hinder the completion of human rights cases that occurred in Papua, especially in Nduga there were 2 (two) Papuan civilians who were pushed by the organization because they were suspected of being an Free Papua organization, even though the Government had seeing the brutal action, there was no firm action to resolve the case clearly. President Jokowi's instruction has an agenda to settle the people and improve the welfare of Papua, but President Jokowi only prioritizes infrastructure or development in Papua, even though the president has seen human rights. Before Jokowi was inaugurated as President during the 2019 Presidential Election, Jokowi would have done well in resolving human rights that occurred in Indonesia, especially the Papua region which has historically had a lot of human rights, so this is very contrary to Indonesia's high ideology.

Keywords: Human Rights; Government; Ideology; Political Law and Human Rights in Indonesia.

\section{Abstrack}

Pelanggaran HAM di Papua seringkali terjadi (10 tahun terakhir) banyaknya faktor-faktor yang menghambat dalam penuntasan kasus pelanggaran HAM yang terjadi di Papua, terkhusus di Nduga adanya 2 (dua) warga sipil papua dibunuh oleh kalangan militer karena diduga kalangan Organisasi Papua Merdeka, walaupun pemerintah telah mengetahui tindakan brutal tersebut, tidak adanya penindakan tegas untuk menuntas kasus tersebut secara jelas. Dalam Instruksi Presiden Jokowi telah ada agenda untuk menuntaskan pelanggaran HAM dan memperbaiki kesejahteraan rakyat Papua, tetapi Presiden Jokowi hanya memprioritaskan infrastruktur atau pembangunan di Papua, padahal presiden telah mengetahui adanya pelanggaran HAM. Sebelum Jokowi dilantik sebagai Presiden pada saat Pilpres 2019 lalu, Jokowi berjanji akan menuntaskan baik menyelesaikan pelanggaran HAM yang terjadi di Indonesia, khususnya daerah Papua yang selama ini memiliki historis pelanggaran HAM yang sangat banyak, sehingga hal ini sangat bertentangan dengan ideologi Indonesia yang menjungjung tinggi Hak Asasi Manusia.

Kata Kunci: Hak Asasi Manusia; Pemerintah; Ideologi; Politik Hukum dan HAM di Indonesia. 


\section{Pendahuluan}

Tahun 1969 Papua mengintegrasikan dirinya kedalam bagian dari Indonesia melalui Penentuan Pendapat Rakyat (PEPERA) dengan suara buat sebanyak 1025 orang, pemilihan atau referendum yang seharusnya dilakukan secara "one man one vote" dilakukan melalui perwakilan-perwakilan hingga muncul istilah pelesetan "Act of No Choice", naasnya diketahui bahwa Presiden Soeharto melalui Ali Murtopo - seorang tokoh intelijen pada masa orde baru memanipulasi hasil PEPERA, hasil manipulasi yang dilakukan oleh pemerintah Indonesia cukup keji, karena pemilihan dilakukan dengan intimidasi dan persekusi serta adanya peran intervensi dari pemerintah Australia untuk mencegah kemerdekaan Papua. ${ }^{1}$ Intervensi pemerintah Australia tercatat dalam sejarah ketika Papua Raad yang menolak integrasi Papua ke Indonesia, ditahan dan diasingkan oleh Australia ke Pulau Manus, Papua Nugini, sebab anggota Papua Raad akan bertolak ke New York untuk menolak hasil PEPERA. ${ }^{2}$ Dengan adanya hasil yang dimanipulasi oleh Pemerintah Republik Indonesia, timbul suatu kesenjangan pemahaman historis akan sejarah Papua, dimana pemahaman historis ini berawal dari perbedaan ras masyarakat Papua (ras Austromelanesoid) dengan masyarakat Indonesia pada umumnya (ras Mongoloid) hal ini menyebabkan rasialisme begitu sering terjadi, tidak adanya jejak partisipasi masyarakat Papua dalam New York Agreement untuk menentukan nasib Papua, serta manipulasi dan keserakahan Pemerintah dengan dalil persatuan Indonesia. ${ }^{3}$ Hal ini merupakan titik lahirnya gerakan separatis Organisasi Papua Merdeka (OPM) yang beranggapan bahwa Papua bukan merupakan bagian dari Indonesia dan masyarakat Papua yang proIndonesia, sehingga di Papua adanya masyarakat yang terpecah belah, sehingga banyak aksi, penolakan, demonstrasi, dan kerusuhan di Papua.

1 Danial A. Futaki, [et.,al.], 'Hak Memperoleh Informasi dan Analisa Hukum dalam Siaran Pers oleh KEMKOMINFO tentang Pemblokiran Layanan Data di Papua dan Papua Barat' (2020) ALSA Indonesia Legal Review Competition.[2].

2 Andreas Harsono, 'Ricuh di Papua Ngeributin Apa Sih? Ft. Andreas Harsono' (2019 Podcast Asumsi Bersuara).

3 Yulia Sugandi, Analisis Konflik dan Rekomendasi Kebijakan Mengenai Papua (Friedrich Ebert Stiftung 2008).[4]. 
Sekitar tanggal 2 Desember 2018, telah terjadi penembakan di daerah Nduga yang dilakukan oleh Kelompok Kriminal Bersenjata-Organisasi Papua Merdeka (KKB-OPM) terhadap para pekerja PT Istaka Karya yang terlibat dalam proyek pembangunan jembatan Trans-Papua. Hal yang memicu KKB-OPM melakukan penembakan tersebut adalah dikarenakan ada seorang pekerja jembatan TransPapua mengambil foto pada saat HUT Tentara Pembebasan Nasional-Organisasi Papua Merdeka (TPN-OPM) yang membuat mereka marah dan sehingga melakukan penembakan terhadap pekerja jembatan Trans-Papua. Beberapa dari kalangan jurnalis menjelaskan bahwa kejadian tersebut merupakan propaganda menjelaskan bahwa masyarakat Papua itu sangat brutal dan berbeda dengan masyarakat Indonesia pada umumnya. Tetapi beberapa dari kalangan media berpendapat lain bahwa tindakan penembakan yang dilakukan oleh KKB-OPM terhadap pekerja Trans-Papua tersebut bertujuan untuk melawan pemerintah terkait pembangunan infrastruktur yang tidak dapat menyelesaikan permasalahan provinsi Papua yang ingin merdeka.

Gerakan dari OPM ini mengakibatkan sensitivitas dari kalangan militer meningkat, dikarenakan adanya anggota dari OPM melakukan penyusupan pada warga sipil papua, khususnya di daerah Nduga, yang mengakibatkan kesulitan dari pihak aparat penegak hukum dalam membedakan mana yang murni warga sipil dan anggota OPM sendiri. Dapat diketahui kerusuhan yang terjadi di Nduga, Papua terus berlangsung selama 2 tahun dan masih terus berlangsung, yang mengakibatkan tewasnya warga sipil yang dilakukan oleh aparat penegak hukum (TNI) yang terjadi pada tanggal 18 Juli 2020 silam. Elias dan Salu Karunggu, dengan para warga yang akan menyeberang dari kampong Masanggarok yang akan menujju ibu kota Kenyam, pada saat para warganya sudah sampai tetapi kedua ornag ini tidak sampai pada ibu kota tersebut, dan dikabarkan mereka tewas ditembak anggota Tim Satgas Pamtas Yonif PR 330/TD, dikarenakan Kepala penerangan Komando Gabungan Wilayah Pertahanan III Kolonel Czi Gusti Nyoman Suriastawa mengatakan dengan yakin bahwa kedua anak dan bapak 
ini merupakan anggota bersenjata pro-kemerdekaan senjata. ${ }^{4}$ Tudingan bahwa keduanya merupakan anggota pro-kemerdekaan dibantah oleh juru bicara TPNPBOPM Sebby Sambom, yang menyebut keduanya bukan anggota, kemudian Ketua DPRD Nduga Ikabus Gwijangge mengatakan keduanya adalah pengungsi dari Distrik Yal yang selama beberapa waktu terakhir tinggal di ibu kota Kenyam, sang anak bekerja sebagai tukang sensor atau pemotong kayu di hutan yang sering membantu masyarakat membangun rumah serta keduanya merupakan keluarga Sekretaris Daerah Nduga, Namia Gwijangge. ${ }^{5}$ Sudah beberapa kali provinsi Papua mengalami tindakan diskriminatif yang dilakukan oleh berbagai kalangan, diantaranya adalah dari gerakan separatis sampai pada aparat penegak hukum.

Pada faktanya dari zaman kepemimpinan Soekarno sampai Jokowi perkembangan yang begitu pesat dari segala segi dan bidangnya hanya terdapat pada Pulau Jawa dibandingkan dengan Pulau Sumatra, Kalimantan, dan Papua. UU 39 Tahun 1999 Tentang Hak Asasi Manusia menyatakan bahwa pemerintah wajib dan bertanggung jawab menghormati, melindungi, menegakkan, dan memajukan hak asasi manusia. Hal ini menunjukkan bahwa kesejahteraan sosial yang ada di Indonesia masih belum merata dan bahkan jauh dari keadilan bagi seluruh masyarakat Indonesia. Negara Kesatuan Republik Indonesia, didesain sebagai Negara Kesejahteraan (welfare state) dapat dilacak dari bunyi pembukaan UUD 1945 bahwa "Pemerintah melindungi segenap bangsa dan seluruh tumpah darah, memajukan kesejahteraan umum dan mencerdaskan kehidupan bangsa”, selain itu beberapa Pasal dalam UUD 1945 mencerminkan pula nilai dasar dari Negara Kesejahteraan (welfare state). ${ }^{6}$ Yang terdapat dalam Pasal 27 ayat (2) dan Pasal 28A yang menjelaskan dalam hal setiap masyarakat Indonesia memiliki hak untuk hidup yang lebih baik bagi kemanusiaan dan untuk bertahan hidup serta kehidupannya.

\footnotetext{
${ }^{4}$ Rachmawati, 'Konflik Nduga Papua, Korban Berjatuhan dan Demonstrasi Tuntut Keadilan',([s.n], 2020) <www.regional.kompas.com> tanggal diakses 9 Oktober 2020.

5 ibid.

${ }^{6}$ Oman Sukmana, 'Konsep dan Desain Negara Kesejahteraan (Welfare State)' (2016) 2 Jurnal Sospol.[2].
} 
Secara singkat didefinisikan sebagai suatu negara dimana pemerintahan negara dianggap bertanggung jawab dalam menjamin standar kesejahteraan hidup minimum bagi setiap warga negaranya. ${ }^{7}$ Mengacu dari hal tersebut Indonesia masih belum dapat dikatakan sebagai Negara Kesejahteraan (Welfare State) dikarenakan masih banyaknya ketimpangan dan ketidakadilan yang dialami oleh masyarakat Indonesia di wilayah Timur, melihat meningkatnya kasus pelanggaran Hak Asasi Manusia yang terjadi di Nduga, Papua seharusnya Pemerintah Indonesia lebih mengkonsentrasikan perhatian untuk mengatasi kejadian naas tersebut, selain adanya pelanggaran HAM, masyarakat Papua secara umum selalu mengalami tindakan diskriminatif dan terkucilkan dari Indonesia, baik dalam kondisi politik, sosial, keamanan, kesehatan, dan pemerataan perekonomian. Dalam menciptakan good governance, harus diproporsionalkan dengan rule of law yang memiliki karakter sebagai berikut adalah supremasi hukum (the supremacy of law), kepastian hukum (legal certainty), hukum yang responsif, penegakkan hukum yang konsisten, adanya independensi dalam peradilan dan non-diskriminatif. ${ }^{8}$ Substansi hukum mengedepankan keadilan serta tanpa pandang bulu, terkhusus dalam hak asasi manusia. Dalam kaitannya dengan kejadian di Papua, seharusnya setiap warga negara berhak atas tuntutan pemenuhan tanggung jawab negara dalam meningkatkan kesejahteraan umum dan mencerdaskan kehidupan bangsa serta dalam melindungi segenap bangsa dan tumpah darah Indonesia. ${ }^{9}$ Berdasarkan teori kedaulatan rakyat yang dijelaskan oleh Imanuel Kant menjelaskan bahwa tujuan negara itu adalah untuk menegakkan hukum dan menjamin kebebasan daripada warga negaranya.10 Sudah seharusnya pemerintah melakukan pengawasan lebih khusus dan perhatian yang lebih kepada Papua, dilihat Indonesia menggunakan ideologi pancasila dan UUD 1945 yang diatur mengenai berbagai kesamaan dalam berbagai hal bagi masyarakat Indonesia tanpa terkecuali.

7 ibid.

8 Bagian Protokol Dan Komunikasi Pimpinan,'Pengertian, prinsip dan Penerapan Good Governance Di Indonesia', ([s.n], 2017) < www.bulelengkab.go.id>, tanggal diakses 15 Oktober 2020.

9 Jimly Asshiddiqie, Pengantar Ilmu Hukum Tata Negara 9PT RajaGrafindo Persada 2009).[365].

${ }_{10}$ Soehino, Ilmu Negara (Liberty 2013).[161]. 


\section{Metode Penelitian}

Metode penelitian yang digunakan dalam pembuatan jurnal ilmiah ini adalah dengan menggunakan metode yuridis normatif. Penelitian yang bersifat yuridis normatif mengkaji isu-isu hukum dan sekaligus memberikan preskripsi apa yang seyogyanya. ${ }^{11}$ Penelitian ini menggunakan pendekatan konseptual (Conceptual Approach) yang merujuk pada prinsip-prinsip hukum yang dikemukakan oleh para sarjana hukum atau doktrin-doktrin hukum, ${ }^{12}$ dan pendekatan kasus (Case Approach) yang berdasarkan atas kasus yang sedang atau telah terjadi dan kemudian dianalisis untuk menemukan jawaban dari permasalahan kasus tersebut. Sumber bahan hukum yang digunakan dalam penelitian ini terdiri dari sumber hukum primer yang mencakup peraturan perundang-undangan serta teori-teori hukum dan sumber hukum sekunder berdasarkan dokumen resmi, publikasi tentang hukum yang meliputi: buku teks, kamus-kamus hukum, jurnaljurnal hukum. ${ }^{13}$

Metode pengumpulan bahan hukum terdiri atas studi peraturan perundangundangan merupakan suatu upaya untuk menelaah dan memahami peraturan perundang-undangan yang mengatur mengenai rumusan masalah dalam penelitian ini, dan kedua mengenai studi kepustakaan digunakan untuk mencari konsep, teori, dan pendapat yang berkaitan dengan rumusan masalah dalam penelitian ini, untuk kemudian bahan yang terkumpul dilakukan analisis dengan cara, pertama identifikasi hukum dan mengeliminasi hal-hal yang tidak relevan untuk menetapkan isu hukum yang hendak dipecahkan, kedua dalam pengumpulan bahan hukum yang sekiranya dipandang memiliki relevansi maka bahan-bahan non hukum diikutsertakan, ketiga melakukan telaah isu hukum yang diajukan berdasarkan bahan hukum yang terkumpul, keempat menarik kesimpulan dalam bentuk argumentasi hukum yang menjawab isu hukum, dan kelima memberikan preskripsi berdasarkan argumentasi yang telah dibangun dalam kesimpulan. ${ }^{14}$

\footnotetext{
${ }^{11}$ Peter Mahmud Marzuki, Penelitian Hukum (Kencana Prenada Media Group 2009).[141].

12 ibid. [178].

13 ibid.[141].

14 ibid.[71].
} 


\section{Problematika Penuntasan Kasus Pelanggaran HAM yang Kunjung Belum}

\section{Selesai}

Negara Indonesia merupakan negara yang menganut paham konstitusi dengan dituangkannya UUD 1945 sebagai dasar negara, diharapkan dengan adanya dasar tersebut maka seharusnya adanya esensi konstitusionalisme di Indonesia, yang memberikan jaminan yang sungguh-sungguh atas perlindungan HAM melalui distribusi kekuasaan yang seimbang dan demokratis bukanlah pemerintahan konstitusional. ${ }^{15}$ Tindakan pemerintah yang melanggar prinsip konstitusionalisme terus melanggar HAM, selalu dapat dipatahkan dengan adanya baju hukum berupa UU atau peraturan perundang-undangan lainnya telah menyebabkan terjadinya pergeseran prinsip dan konsesi dari negara hukum menjadi negara undang-undang, di dalam negara undang undang yang seperti ini ukuran-ukuran kebenaran bukan lagi rasa keadilan dan kepatutan dengan sukma etika yang tinggi melainkan kalimat-kalimat undang-undang yang pembuatannya dilakukan melalui rekayasa bagi kepentingan pemerintah, sehingga dengan sendirinya legitimasi yang dimiliki pemerintah dalam menyelenggarakan kekuasaan juga lebih merupakan legitimasi formal atau legitimasi yang penuh kontradiksi-kontradiksi, serta dilain sisi UUD tidak melakukan elaborasi konstitusionalisme secara ketat dan mudah dimanipulasi melalui formalitas-formalitas. ${ }^{16}$

Politik Hukum HAM di Indonesia memiliki polemik yang sangat sukar untuk diselesaikan, dimana polemik tersebut apakah benar-benar sungguh diselesaikan secara hukum di pengadilan atau akan diberi baju hukum bagi proses pemutihan dan rekonsiliasi secara elegan, serta adanya sistem politik yang tidak demokratis dibangun menggunakan alasan-alasan UUD NRI 1945 maka jangka panjang politik hukum HAM harus memberi landasan konstitusional bagi keharusan munculnya sistem politik yang demokratis melalui perubahan atau amandemen atas UUD 1945.

\footnotetext{
${ }^{15}$ Adnan Buyung Nasution, The Aspiration for Constitutional Government in Indonesia, a Socio-Legal Study of the Indonesian Konstituante 1956-1959 (Pustaka Sinar Harapan 1992).[120].

16 Moh. Mahfud MD, 'Politik Hukum Hak Asasi Manusia di Indonesia' (2000) 7 Jurnal Hukum.[3].
} 
Disitulah yang menyebabkan penegakan hukum di Papua dalam menuntaskan kasus pelanggaran HAM sangat sulit untuk diselesaikan. Problematika dalam penyelesaian kasus pelanggaran HAM oleh kalangan TNI terhadap masyarakat Nduga adalah dari sisi penegakan hukum yang tidak memperhatikan nilai equality before the law dalam menegakkan suatu keadilan untuk menuntaskan pelanggaran HAM. Provinsi Papua sudah lama sekali mengalami konflik terkait ras maupun warna kulit antara masyarakat Papua dengan kalangan militer. Perjuangan masyarakat papua untuk memperoleh keadilan sampai sekarang belum selesai dan banyaknya pelanggaran HAM. Penegakan hukum yang berlaku di Papua tidak berjalan sesuai dengan nilai filsafat hukum dan banyaknya kepentingan politik yang mengintervensi jalannya penegakan hukum di Papua. Ketika orang Papua diperlakukan tidak manusiawi, harkat dan martabatnya dihina dengan tindakan kekerasan atau pun pembunuhan oleh oknum tertentu baik sipil maupun militer, tidak berlaku hukuman bagi pelakunya dikarenakan adanya kebiasaan tindakan diskriminatif dan represif dari dulu yang sudah menjadi tradisi bagi kalangan militer terhadap masyarakat Papua. ${ }^{17}$ Di samping itu juga, permasalahan terkait otonomi khusus juga masih belum maksimal untuk dilakukan, dimana pada saat kepemimpinan Presiden Abdurahman Wahid yang mengusulkan adanya otonomi khusus tentang pemberian kebijakan khusus bagi papua dengan dibiarkannya bintang kejora sebagai penanda kekuasaan sebagai beragamnya masyarakat Papua (tertera dalam Pasal 2 UU Nomor 21 tahun 2001), tetapi pada era berikutnya, tidak terealisasi otonomi khusus tersebut secara maksimal walaupun sempat dikembangkan lagi oleh kepemimpinan Presiden Susilo Bambang Yudhoyono. ${ }^{18}$ Dalam perkembangannya otonomi khusus selama 20 tahun ini masih memberikan kerugian yang besar kepada masyarakat asli Papua, dalam pemerintahan Presiden Jokowi mengalami kegagalan dalam melakukan upaya dialog damai mengenai otonomi khusus serta adanya perbedaan

${ }^{17}$ Suara Papua, 'Menyusuru Historis Rasis Terhadap Orang Asli Papua' ([s.n], 2019) <www. suarapapua.com>, tanggal diakses 20 Oktober 2020.

18 Chrissen Daulat Marthin Marpaung, 'Papua dan Upaya Saling Memahami'([s.n], 2020) $<$ www.minews.id >, tanggal diakses 23 Oktober 2020. 
kebudayaan yang harus dipersatukan, ditambah lagi adanya kekeliruan ucapan dari Mahfud MD dalam penyampaian pemekaran 3 (tiga) provinsi Papua dan Papua Barat, yang seharusnya adanya persetujuan dari MPR PB dan MPR serta DPR dan DPR PB. ${ }^{19}$ Indonesia menganut prinsip negara hukum dan demokrasi serta memiliki konstitusi yang menyatakan pemihakan pada perlindungan HAM, ternyata Indonesia senantiasa terjadi pelanggaran HAM yang sangat banyak, diantaranya dilakukan oleh aparat secara masif. ${ }^{20}$ Undang- undang baik peraturan perundangundangan yang dibuat oleh pemerintah tidak mampu untuk menuntaskan kasus pelanggaran HAM yang terjadi di Papua dikarenakan banyaknya intervensi dari pihak luar sehingga masuknya konflik kepentingan dalam penegakan hukum di Papua dan menyebabkan para penegak hukum sulit untuk menyelesaikan kasus pelanggaran HAM yang terjadi di Nduga, Papua. Selain permasalahan rasialisme, permasalahan ideologi yang berbeda antara kalangan militer dengan masyarakat Nduga juga menjadi suatu masalah penegakan hukum HAM yang kunjung belum selesai dalam menuntaskan kasus pelanggaran HAM Papua. Perbedaan pandangan ini justru memicu munculnya konflik yang berkepentingan di Nduga Papua, sehingga perlunya meluruskan perbedaan persepsi ini agar mata rantai konflik bisa diputuskan kemudian melalui resolusi bersama, dan apabila diabaikan maka strategi yang ditempuh pemerintah tentu merupakan upaya untuk menyelesaikan sebagian persoalan di Papua dan tidak menutup kemungkinan bahwa aksi-aksi protes terhadap pemerintah akan terus terjadi kedepan di tengah suasana kesibukan pemerintah untuk membangun Papua. ${ }^{21}$ Apabila kepentingan politik yang masuk kedalam Papua, maka hukum tersebut gagal dalam menegakkan keadilan dan hukum tersebut menjadi alat penguasa untuk melanggengkan kekuasaannya (Abuse of Power), banyaknya pelanggaran dan kekerasan yang terjadi di papua didasarkan adanya perbedaan kepentingan antara kalangan militer dengan masyarakat Papua

\footnotetext{
${ }_{19}$ Suara Papua, '20 Tahun Otsus Harus Diselesaikan Dengan Dialog' ([s.n], 2020) <www. suarapapua.com> tanggal diakses 23 Oktober 2020.

${ }^{20}$ Moh. Mahfud MD, Op.Cit.[3].

${ }_{21}$ Suara Papua, 'Ostsus Gagal sebagai Resolusi Konflik Papua' ([s.n], 2020) <www.suarapapua.com>tanggal diakses 16 Oktober 2020.
} 
khususnya yang masih memegang teguh adat-istiadatnya, terkhusus adanya penembakan dua warga sipil Papua oleh kalangan militer.

\section{Hambatan Penegakan Hukum dalam Penyelesaian Kasus Pelanggaran HAM di Nduga Papua}

Berpacuan dari politik hukum HAM yang kurang maksimal di Indonesia serta adanya perbedaan kepentingan tersebut, menimbulkan hambatan-hambatan dalam penegakan hukum untuk menyelesaikan pelanggaran HAM yang dilakukan kalangan militer terhadap masyarakat Nduga Papua. Penyebab terjadinya pelanggaran HAM itu adalah sistem politik yang tidak demokratis, sedangkan sistem yang tidak demokratis itu dibangun oleh pemerintah dengan menggunakan alasan-alasan yang diambil dari UUD NRI 1945 sendiri, bahkan seiring dikatakan justru untuk melaksanakan pesan UUD NRI 1945 (UUD NRI 1945 sebagai bantuan loncatan), diluar dari salah satu kendala tersebut adanya dua kendala utama dalam upaya untuk menyelesaikan secara hukum atas pelanggaran HAM: pertama, kendala teknis-prosedural yang menyangkut pembuktian secara hukum, ketersediaan aturan hukum dan kedua terkait kendala politis yang ditandai oleh adanya kekuatan besar untuk menghambat upaya penyelesaian melalui pengadilan. ${ }^{22}$ Adapun kendala prosedural yang terjadi adalah adanya kebingungan antara prinsip kepastian hukum (dengan melihat asas legalitas maka pelanggaran ham sebelum adanya UndangUndang tidak bisa dijatuhkan sanksi) dan penegakan keadilan (dengan melihat asas retroaktif bahwa kejadian sebelum adanya UU dapat dikenakan sanksi berupa pemberlakuan surut Undang-undang yang bersangkutan) Prinsip demi kepastian hukum dan demi tegaknya keadilan yang seharusnya dijadikan prinsip yang saling melengkapi kemudian dijadikan alat tolak tarik untuk mencari kemenangan dalam menangani perkara, ${ }^{23}$ sedangkan dari kendala politis yang terkait dengan upaya tangan-tangan kuat untuk menghalangi proses hukum atas pelanggaran HAM

${ }^{22}$ Moh. Mahfud MD, Op.Cit.[24]. 1999).[24].

${ }_{23}$ Moh. Mahfud MD, Hukum dan Pilar-pilar Demokrasi (Gama Media dan Ford Foundation 
menjadi jauh lebih serius daripada persoalan-persoalan teknis prosedural hukum, upaya blokade atau penghambatan terhadap upaya penyelesaian hukum atas kasuskasus masa lalu ini bahkan banyak dipercaya telah muncul dalam bentuknya yang sangat mengerikan yakni pemicuan kerusuhan dan tindak kekerasan politik yang sambung menyambung di berbagai tempat di tanah air sehingga pelanggaran HAM secara masif dan berat kembali terjadi tanpa dapat dikendali oleh pemerintah atau aparat keamanan. Hal tersebut sungguh disayangkan dari negara Indonesia yang seharusnya melindungi segenap masyarakat Indonesia mulai dari ujung timur sampai barat, adanya ideologi negara serta cita-cita luhur bangsa Indonesia untuk menjunjung tinggi HAM setiap masyarakat Indonesia, tetapi hal tersebut tidak terjadi dan sebaliknya, bahwa pelanggaran HAM terjadi di Indonesia, khususnya di Papua, dimana dapat diketahui akhir-akhir ini ada penembakan oleh kalangan militer terhadap warga sipil Nduga (ayah dan anak) yang disangka merupakan anggota OPM (Organisasi Papua Merdeka), tindakan aparat keamanan menembak dua warga Papua ini menunjukkan negara kerap bertindak represif, tindakan ini tak terukur, brutal dan merupakan pelanggaran hak hidup mereka (tergolong jenis pembunuhan tidak sah atau unlawful killing). ${ }^{24}$ Akibat insiden pembunuhan anak dan bapak warga Nduga, masyarakat Papua melakukan demonstrasi untuk menuntut keadilan hak asasi manusia dalam penembakan oleh pasukan TNI pada 18 Juli, hal ini merupakan kesekian kalinya warga Nduga menjadi korban dari konflik antara pasukan TNI dan TPNPB-OPM, dimana merujuk data Tim Kemanusiaan sedikitnya 241 warga Nduga tewas di tengah konflik bersenjata antara pasukan gabungan TNI dan kelompok pro-kemerdekaan di Nduga, lebih lanjut Ikabus mempertanyakan tindakan pasukan TNI yang bukannya melakukan penegakan hukum, tapi langsung menembak kedua orang itu, dimana seharusnya diadili, dan langsung tembak mati seperti tidak ada penegakan hukum. ${ }^{25}$

\footnotetext{
${ }^{24}$ Amnesty Indonesia, 'Penembakan Ayah-Anak di Nduga Kembali Tunjukkan Negara Bertindak Represif' ([s.n], 2020) <www.amnesty.id> tanggal diakses 19 Oktober 2020.

${ }^{25}$ Ayomi Amindoni, 'Papua konflik di Nduga: 'Korban terus berjatuhan', demonstrasi tuntut keadilan warga yang ditembak, pemerintah diminta ubah 'pola' kebijakan' ([s.n], 2020) <www.bbc. com> tanggal diakses 19 Oktober 2020.
} 


\section{Efektifitas Penegakan Hukum Sesuai dengan Prinsip Negara Hukum dan}

\section{HAM dalam Kasus Penyelesaian Penembakan Warga Sipil di Nduga}

Pada dasarnya suatu negara memiliki sebuah konsep dan prinsip negara hukum, dimana menurut Ten Berge suatu negara hukum harus memiliki prinsip yang terdiri dari asas legalitas, yang artinya ada pembatasan kebebasan warga negara oleh pemerintah kemudian undang-undang secara umum harus memberikan jaminan terhadap warga negara dari tindakan pemerintahan yang sewenang-wenang, kolusi, dan berbagai tindakan yang merugikan rakyat, kedua adanya perlindungan hak-hak asasi, ketiga pemerintah terikat pada hukum, adanya penegakan hukum secara tegas dan benar, dan pengawasan oleh hakim yang merdeka. ${ }^{26} \mathrm{Hal}$ ini sesuai juga dengan konsep negara hukum yang dianut oleh Indonesia yaitu konsep negara hukum pancasila yang menjelaskan bahwasanya negara ini harus menjunjung tinggi kebebasan memeluk agama (dalam arti positif, tidak dikenalnya ada ateisme) dan adanya jaminan perlindungan hak asasi manusia secara kekeluargaan dan kemanusiaan. Apabila ditinjau dari good governance menurut Sedarmayanti mengemukakan arti good governance mengandung dua pengertian yaitu, nilai-nilai yang menjunjung tinggi kehendak rakyat, dan nilai-nilai yang dapat meningkatkan kemampuan rakyat dalam pencapaian tujuan nasional, kemandirian pembangunan berkelanjutan dan keadilan sosial, dan adanya aspek fungsional dari pemerintahan yang efektif serta efisien dalam pelaksanaan tugasnya untuk mencapai tujuan tersebut. ${ }^{27}$ Adapun unsur atau karakteristik good governance menurut UNDP yang sesuai dengan pelanggaran HAM adalah, ${ }^{28}$ pertama rule of law adalah kerangka hukum harus adil dan dilaksanakan tanpa pandang bulu terutama hukum untuk hak asasi manusia dan transparansi adalah keterbukaan dibangun atas dasar kebebasan arus informasi, sumber informasi tersebut harus dengan mudah diterima

\footnotetext{
${ }^{26}$ Nurul Qamar, Hak Asasi Manusia Dalam negara hukum Demokrasi (Human Rights In Democratiche Rechtsstaat) (Sinar Grafika 2013).[30].

27 Soedarmayanti, Good Governance: Kepemerintahan yang Terlaksana dalam Rangka Otonomi Daerah (Mandar Maju 2002).[6].

28 Nelly Pinangkaan, 'Good Governance dan hak Asasi Manusia Dalam Keterbukaan Informasi' (2016) 4 Lex et Societatis.[3].
} 
oleh mereka yang membutuhkan. Sehubungan dengan prinsip dan kriteria dari good governance berdasarkan kasus penembakan warga sipil di Nduga Papua yang dilakukan oleh kalangan militer, telah terjadinya penyimpangan dari unsur mengenai rule of law dan transparansi, dikarenakan seharusnya peran pemerintah seharusnya melindungi warganya, dikarenakan hal tersebut merupakan kewajiban dari negara dan merupakan HAM dari setiap warga negara di Indonesia, dimana pemerintah dengan perwakilan TNI di Nduga Papua telah melakukan pelanggaran HAM berat dikarenakan tindakan represif yang sangat brutal tersebut, serta tidak adanya kejelasan informasi bagaimana pemerintah menyikapi hal tersebut dan bagaimana penanganan atau sanksi yang diberikan kepada petugas TNI tersebut untuk mendapatkan ganjaran yang setimpal.

Perkembangan penegakan hukum di Papua banyak bermasalah dalam menyelesaikan suatu kasus hukum yang sedang terjadi. Banyak sekali intervensiintervensi dari kalangan politis maupun pihak luar yang merusak sistem penegakan hukum di Papua sehingga seringkali terjadi konflik kepentingan dalam mencari suatu keadilan di Nduga. Penegakan hukum di Papua masih belum sejalan dengan prinsip negara hukum dan HAM karena masih banyak kasus HAM yang masih belum tertuntaskan, berbeda dengan provinsi lainnya beberapa penegakan hukum di daerah lain sejalan dengan prinsip good governance dalam menuntaskan suatu kasus di daerah masing-masing. Pemenuhan tanggung jawab ganti rugi pemerintah terhadap masyarakat Nduga belum dilaksanakan dan belum ada penindakan lebih lanjut kalangan militer yang melakukan penembakan terhadap dua pekerja, seharusnya pemerintah yang merupakan wakil rakyat harus bisa mensejahterakan rakyatnya dan penegakan hukum di Papua harus bebas dari kepentingan lainnya karena bahwasanya peradilan merupakan lembaga yang bersifat imparsial atau independen sesuai dengan dasar hukum UU 46 Tahun 2009 yang mengatur mengenai kekuasaan kehakiman yang bersifat imparsial. Menurut Philipus Mandiri Hadjon, perlindungan hukum bagi rakyat dapat dibagi menjadi dua macam, yaitu perlindungan hukum preventif dan perlindungan hukum represif. Dalam hal hukum preventif, masyarakat memiliki kesempatan untuk memberikan keberatan sebelum 
keputusan pemerintah, artinya perlindungan hukum yang preventif bertujuan untuk mencegah terjadinya sengketa, sedangkan sebaliknya perlindungan hukum yang represif bertujuan untuk menyelesaikan sengketa. ${ }^{29}$

\section{Perlindungan Hak Asasi Manusia Seluruh Masyarakat Indonesia yang Terjamin}

Pada dasarnya setiap orang memiliki Civil Rights yang harus dilindungi dan dijamin oleh pemerintah, dimana yang berkaitan dengan hak untuk hidup dan mempertahankan kehidupan, larangan perbudakan, kebebasan bergerak, kebebasan untuk mengemukakan pikiran dan pendapat, larangan penangkapan, penahanan secara sewenang-wenang, dan pengasingan. ${ }^{30}$ Berdasarkan jenis hak asasi manusia tersebut, terdapat kehilangan perlindungan di Nduga Papua, dikarenakan macammacam jenis hak asasi manusia tersebut dirampas oleh para penegak hukum, khususnya kalangan militer yang bertugas di Nduga, Papua, sehingga masyarakat Nduga memiliki hak untuk mengajukan tuntutan atas hak-hak mereka yang dirugikan oleh kalangan militer, terkhusus bagi warga Nduga yang kehilangan nyawanya, selain dari sisi masyarakat Nduga, pemerintah seharusnya tanggap dalam melihat banyaknya kasus pelanggaran yang terjadi di Papua, khususnya Nduga, seharusnya pemerintah melakukan tindakan cepat berupa evakuasi korban dan para saksi mendapatkan perlindungan dari pemerintah agar para saksi memberikan penjelasan tentang keadaan fakta yang jelas dan imparsial dalam pendorongan secara proporsional melalui jalur hukum. ${ }^{31}$ Di dalam instruksi Presiden Jokowi, menjelaskan bahwa target pemerintah adalah untuk memprioritaskan provinsi Papua dari visi misi Jokowi sejak dilantik tetapi hanya memperhatikan infrastruktur maupun pembangunan saja dan tidak menuntaskan kasus pelanggaran HAM yang terjadi di Nduga, Papua. Melalui fakta adanya pengungsi di kabupaten Nduga

${ }^{29}$ Bahder Johan Nasution, Negara Hukum Dan Hak Asasi Manusia (CV. Mandar Maju 2014).[258].

30 Nurul Qamar, Op.Cit.[96-97].

31 Devina Halim, '3 Saran Imparsial untuk Penanganan Pembantaian Pekerja di Nduga Papua' ([s.n] 2018) <www.nasional.kompas.com> tanggal diakses 21 Oktober 2020. 
sejak 2018 sampai dengan 2020 ini merupakan korban dari instruksi presiden yang dilakukan tanpa mengikuti ketentuan Konvensi Jenewa Tahun 1949 dengan UU No. 59 Tahun 1950 tentang Ikut-Serta Negara Republik Indonesia dalam seluruh Konvensi Jenewa tanggal 12 Agustus 1949. ${ }^{32}$ Pasal 101 UU Nomor 29 Tahun 1999 menjelaskan Seluruh masyarakat, baik pribadi maupun kelompok memiliki hak untuk melaporkan atas adanya tindakan pelanggaran hak asasi manusia kepada lembaga yang menangani HAM seperti Komnas HAM dan sejenisnya, sehingga berpacuan dari Pasal tersebut masyarakat di Nduga maupun kelompok masyarakat (class action) dapat mengajukan laporan atas terjadinya banyak kasus pelanggaran HAM di Nduga. Walaupun di peraturan telah ditentukan demikian, terdapat banyak polemik yang muncul seperti banyaknya warga di Nduga yang tidak memahami hal tersebut, pemerintah atau laporan tersebut tidak adanya kelanjutan mengenai bagaimana proses penyelesaian kasus tersebut, dan kemungkinan terburuk adanya asumsi bahwa pemerintah menganggap sepele kasus pembunuhan di Nduga serta beralasan adanya pengalihan isu dengan peristiwa yang lebih genting. Korban akibat pelanggaran HAM yang dilakukan oleh seseorang (si pelaku) dapat diberikan restitusi dan kompensasi, menurut Stephen Scaffer (the victim and his criminal) dikemukakan lima sistem pemberian restitusi dan kompensasi kepada korban antara lain:

a. Batas kerugian (damage) yang bersifat keperdataan diberikan melalui proses perdata. Sistem ini memisahkan tuntutan ganti rugi korban dari proses pidana;

b. Dalam proses pidana, kompensasi yang diberikan bersifat perdata;

c. Restitusi yang dipadukan antara sifat perdata dan pidana, berikan dalam pidana. Walaupun restitusi disini tetap bersifat keperdataan, namun tidak diragukan sifat pidana (punitif) nya. Kompensasi (compensatory fine) merupakan salah satu bentuk Restitusi. Denda ini merupakan kewajiban yang bernilai uang (monetary obligation) yang dikenakan kepada terpidana sebagai suatu bentuk pemberian ganti rugi kepada korban disamping pidana yang seharusnya diberikan;

d. Kompensasi yang bersifat perdata, diberikan melalui proses pidana dan disokong oleh sumber-sumber penghasilan negara. Disini kompensasi tidak mempunyai aspek pidana apapun, walaupun diberi dalam proses pidana. Jadi

32 Suara Papua, 'Inpres Jokowi Berhasil Melahirkan Pelanggaran HAM dan Pengungsi di Papua’ ([s.n] 2020) <www.suarapapua.com> tanggal diakses 21 Oktober 2020. 
tetap merupakan lembaga keperdataan murni, tetapi negara yang memenuhi/ menanggung kewajiban ganti rugi yang dibebankan pengadilan pada pelaku. ${ }^{33}$

Akibat dari kasus Penembakan 2 (dua) warga Nduga oleh kalangan militer (Selu Karunggu dan Elias Karunggu) yang dilakukan tanpa upaya penangkapan dan interogasi tetapi langsung melakukan eksekusi penembakan mati oleh kedua warga sipil tersebut, sudah selayaknya apabila pelaku penembak (dari kalangan militer) untuk mempertanggungjawabkan perbuatan yang brutal tersebut, sehingga secara formil harus diadili berdasarkan peradilan militer serta dapat dikaitkan dengan pengadilan hak asasi manusia. Di lain sisi penembakan oleh kalangan militer merupakan suatu pelanggaran kode etik dari TNI, dikarenakan penembakan terhadap warga sipil sampai meninggal dan brutal merupakan suatu tindakan keji dan tidak termaafkan dalam kode etik TNI, sehingga yang dapat dikenakan pertanggungjawaban pidana adalah komandan atau atasan dari prajurit yang menyuruh lakukan perbuatan penembakan tersebut, hal ini sesuai dengan ketentuan dari Undang-Undang Nomor 26 Tahun 2000 tentang Pengadilan Ham yang terdapat dalam ketentuan Pasal 37 jo. Pasal 42, berdasarkan ketentuan dari Pasal 37 UndangUndang Nomor 26 Tahun 2000 menjelaskan siapapun yang melakukan kejahatan atau tindakan berdasarkan Pasal 9 huruf a, b, c, d, e atau j mendapatkan sanksi pidana mati atau seumur hidup serta penjara paling lama 25 (dua puluh lima) tahun dan paling sedikit 10 (sepuluh) tahun. Sedangkan dalam Pasal 42 ayat (1) menjelaskan komandan militer bertanggungjawab atas tindakan yang dilakukan oleh anak buah atau prajurit militer dibawahnya, baik secara langsung (mengetahui salah dan tetap dilakukan) maupun tidak langsung (tidak mengetahui secara pasti) hal tersebut merupakan akibat dari tidak dlakukan pengawasan atau sengaja diberikan amanat yang tidak benar dengan peraturan perundang-undangan. Apabila dilihat dari undang-undang tentang peradilan hak asasi manusia, maka prajurit tni yang melakukan penembakan dua warga Nduga berdasarkan dari arahan atau seizin dari komandan prajurit, maka komandan tersebut dapat dijatuhi pertanggungjawaban

33 H. Ediwarman, 'Perlindungan HAM Dalam Proses Peradilan (The Human Rights Protection in The Process of Justice)' (2000) 1 Jurnal Kriminologi Indonesia.[27]. 
pidana berupa pidana paling singkat 10 (sepuluh) tahun penjara sampai paling tinggi adalah hukuman mati, karena hal ini merupakan pelanggaran HAM berat yang dilakukan oleh kalangan militer sebagai perwakilan dari pemerintah, dan apabila disangkutkan dengan peradilan militer, maka dapat pula digabungkan dengan gugatan ganti rugi sesuai dengan ketentuan dalam Pasal 183 UndangUndang Nomor 31 Tahun 1997 Tentang Peradilan Militer, sehingga dalam hal ini diperlukan tindakan tegas dari pemerintah untuk memberikan kepastian hukum dengan cara menindaklanjuti kalangan militer yang melakukan pelanggaran HAM di Nduga, Papua.

\section{Kesimpulan}

Berdasarkan dari sejarah kelam Papua selama kurang lebih 50 (lima puluh) tahun, dimana Papua selalu mendapatkan perlakuan yang tidak manusiawi sebagai bagian dari wilayah Indonesia, serta adanya manipulasi pada era Soeharto yang mengakibatkanawalmulamunculnyaOPM(Organisasi PapuaMerdeka), darisitu titik awal terjadinya banyak pelanggaran HAM, mulai dari pemerkosaan, pembunuhan, perbudakan, intimidasi serta rasialisme yang selalu dirasakan oleh masyarakat Papua. Banyak yang melakukan pembelaan terhadap Papua dan memberikan perlakuan yang sama kepada Papua, adapun upaya pemerintah adalah dengan mengeluarkan kebijakan otonomi khusus pada kepemimpinan Presiden Abdurahman Wahid yang kepada Papua agar memiliki kekhususan dalam hal kebudayaan serta pemberian anggaran, tetapi faktanya otonomi khusus ini yang bermula dari tahun 2001 sampai sekarang kurang lebih 20 tahun dirasa mengakibatkan terusnya pelanggaran HAM, serta adanya hambatan dari politik hukum dan HAM yang terjadi di Indonesia berupa kendala teknis prosedural yang menyangkut pembuktian secara hukum, ketersediaan aturan hukum dan kedua terkait kendala politis yang ditandai adanya kekuatan yang besar untuk menghambat upaya penyelesaian melalui pengadilan, sehingga hal ini merupakan suatu pertentangan dengan makna good governance dalam hal rule of law dan transparansi serta ideologi Indonesia yaitu pancasila serta UUD 1945 yang mengedepankan HAM itu sendiri. Dalam hal ini pemerintah harus 
lebih melihat secara objektif seluruh masyarakat di Indonesia dalam hal penegakan HAM yang maksimal dan merespon laporan yang diajukan oleh masyarakat atau kelompok masyarakat terkait adanya pelanggaran HAM terkhusus di Papua yang notabenenya masih sering terjadi pelanggaran HAM, kemudian perlunya ketegasan pemerintah dalam menindaklanjuti kasus penembakan 2 (dua) warga sipil Papua yaitu Elias Karunggu dan Selu Karunggu harus independen dalam menuntaskan suatu kasus sampai benar-benar selesai.

\section{Daftar Bacaan}

\section{Buku}

Adnan Buyung Nasution, The Aspiration for Constitutional Government in Indonesia, a Socio-Legal Study of the Indonesian Konstituante 1956-1959 (Pustaka Sinar Harapan 1992).

Bahder Johan Nasution, Negara Hukum Dan Hak Asasi Manusia (CV. Mandar Maju 2014).

Jimly Asshiddiqie, Pengantar Ilmu Hukum Tata Negara 9PT (RajaGrafindo Persada 2009).

Moh. Mahfud MD, Hukum dan Pilar-pilar Demokrasi (Gama Media dan Ford Foundation 1999).

Nurul Qamar, Hak Asasi Manusia Dalam negara hukum Demokrasi (Human Rights In Democratiche Rechtsstaat) (Sinar Grafika 2013).

Soedarmayanti, Good Governance: Kepemerintahan yang Terlaksana dalam Rangka Otonomi Daerah (Mandar Maju 2002).

Soehino, Ilmu Negara (Liberty 2013) .

Yulia Sugandi, Analisis Konflik dan Rekomendasi Kebijakan Mengenai Papua (Friedrich Ebert Stiftung 2008).

\section{Jurnal}

Andreas Harsono, 'Ricuh di Papua Ngeributin Apa Sih? Ft. Andreas Harsono',(2019) Jakarta: Podcast Asumsi Bersuara.

Danial A. Futaki, [et.,al.], 'Hak Memperoleh Informasi dan Analisa Hukum 
dalam Siaran Pers oleh KEMKOMINFO tentang Pemblokiran Layanan Data di Papua dan Papua Barat', (2020) ALSA Indonesia Legal Review Competition .

H. Ediwarman, 'Perlindungan HAM Dalam Proses Peradilan (The Human Rights Protection in The Process of Justice)' (2000) 1 Jurnal Kriminologi Indonesia.

Moh. Mahfud MD, 'Politik Hukum Hak Asasi Manusia di Indonesia' (2000) 7 Jurnal Hukum.

Nelly Pinangkaan, 'Good Governance dan hak Asasi Manusia Dalam Keterbukaan Informasi' (2016) 4 Lex et Societatis.

Oman Sukmana, 'Konsep dan Desain Negara Kesejahteraan (Welfare State)'(2016), 2 Jurnal Sospol.

\section{Laman}

Amnesty Indonesia, 'Penembakan Ayah-Anak di Nduga Kembali Tunjukkan Negara Bertindak Represif' ([s.n], 2020) <www.amnesty.id $>$ tanggal diakses 19 Oktober 2020.

Ayomi Amindoni, 'Papua konflik di Nduga: 'Korban terus berjatuhan', demonstrasi tuntut keadilan warga yang ditembak, pemerintah diminta ubah 'pola' kebijakan' ([s.n], 2020) <www.bbc.com> tanggal diakses 19 Oktober 2020.

Bagian Protokol Dan Komunikasi Pimpinan,'Pengertian, prinsip dan Penerapan Good Governance Di Indonesia', ([s.n], 2017) < www.bulelengkab.go.id> tanggal diakses 15 Oktober 2020.

Devina Halim, '3 Saran Imparsial untuk Penanganan Pembantaian Pekerja di Nduga Papua' ([s.n] 2018) <www.nasional.kompas.com> tanggal diakses 21 Oktober 2020.

Rachmawati, 'Konflik Nduga Papua, Korban Berjatuhan dan Demonstrasi Tuntut Keadilan',([s.n], 2020) <www.regional.kompas.com> tanggal diakses 9 Oktober 2020.

Suara Papua, 'Inpres Jokowi Berhasil Melahirkan Pelanggaran HAM dan Pengungsi di Papua' ([s.n] 2020) <www.suarapapua.com> tanggal diakses 21 Oktober 2020. 
Andrean Gregorius: Prinsip Penegakan Hukum...

--halaman ini sengaja dibiarkan kosong-- 